\title{
Perception and needs of older visitors in the Swiss National Park - a qualitative study of hiking tourists over 55
}

\author{
Alice Trachsel \& Norman Backhaus
}

Keywords: older age group, senior citizen, tourism, Swiss National Park

\section{Abstract}

Older people are increasingly active tourists. Better health, an improved financial background and better mobility have let their number as visitors in the Swiss National Park (SNP) steadily increase. This paper aims at ascertaining these older visitors' perception of the SNP. Using a qualitative approach, we interviewed more than a hundred visitors over 55. In addition, we carried out interviews with experts from the region to find out how this clientele is perceived by the tourist industry and the park management. Results show that older people are a visitor group that is very interested in information about the SNP. While still fit, they take their time on the trails and spend more time on observation. Older visitors are very much in favour of the strict rules that apply in the park and resent people breaking these rules. What they most dislike is crowding and noise, a fact that needs close attention from the park management. The tourist industry is very much aware of this tourist group's multiplicator effect and tries to meet their needs as much as possible.
Profile

National Park

Swiss National Park

Mountain range

Alps

Country

Switzerland

\section{Introduction}

Most protected areas in the Alps have become attractive tourist destinations. The Swiss National Park (SNP) receives more than 150000 visitors per year, who are attracted to the park's pristine environment, flora and fauna, and hiking opportunities (Lozza 1996). The SNP, situated between the Engadine Valley and the Val Müstair (4640'2”N, $10^{\circ} 10^{\prime} 3^{\prime}$ E), comprises an area of $170 \mathrm{~km}^{2}$ and an altitudinal range from 1400 to $3100 \mathrm{~m}$. Founded in 1914, it is the oldest national park of the Alps. Since 2010, the area, enlarged by the Val Müstair, forms the UNESCO Biosphere Reserve Swiss National Park / Val Müstair. On weekends with fine weather, thousands of visitors are on the trails and crowding becomes an issue, not least because visitors must stick to the trails and designated picnic areas. A relatively large proportion (27.4\%; unpublished survey of the SNP 2006) of the visitors are older people, a group that receives growing attention from the tourist industry (Prahl 2002). As a result of better health, higher life expectancy and the ability to stay active for a longer period, older people are participating more in tourist and leisure activities than a few decades ago. Their financial means have improved in recent years due to a well functioning pension scheme, which is why they are seen as an important future market. Moreover, they have a disproportionally high interest in nature tourism (Hennig \& Grossmann 2008). Based on experiences in the past, this group of tourists has high standards that are not so easy to meet. This article addresses the needs and wishes of older visitors of the SNP. Qualitative interviews were conducted with people over the age of 55 during summer and autumn 2009 in several resting areas of the park. In addition,

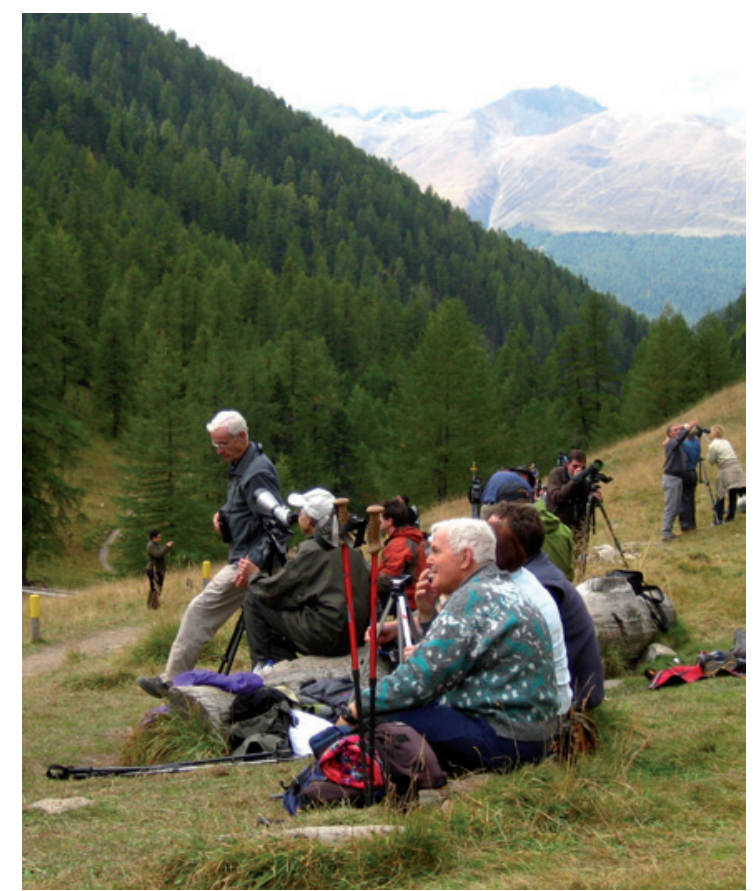

Visitors watching the rut of the red deer at Val Trupchun. (C) Corvin Bulliard

we interviewed experts from the region to find out how this group is seen by the tourist industry. Since summer tourism to the SNP generates up to $50 \%$ of the region's direct and indirect revenue from tourism in 1998 this amounted to CHF 10.2 million (Küpfer 2000) and generated 120 jobs (Cathomas-Bearth 2001) - in-depth information on the growing group of older tourists is important for the region. In this paper, we first give a brief overview of research on older people. Then we present our methods and results. We conclude with some recommendations. 


\section{Older people in tourism research}

As a result of better health, higher life expectations and better financial means, older people are much more active, confident, adventurous and leisure-oriented than a generation before (Scheiner 2001). This has made them the preferred target group for the leisure industry, even though they are not so easily pleased and have high standards (Prahl 2002).

Older people, seniors or third-agers refers to people aged 55 or older. They can be divided into subgroups such as empty nesters (55-64 years; Möller et al. 2007), young seniors (55-69; Nimrod 2008; Thieme 2008), third-agers (65-79; Kochsiek \& Gieselmann 2009), elderly / older seniors (75-90), aged (above 85), and long-lived, reaching 100 years (Prahl \& Schröter 1996). For this investigation, we interviewed mostly empty nesters, young seniors, and third-agers. The interest for nature and conservation increases with age, causing a rise in the age of visitors to the SNP (Hennig \& Grossmann 2008). $61 \%$ of visitors to Berchtesgaden National Park aged 55 and older describe themselves as nature lovers and give nature and landscape as the principal reasons for their visit. Moreover, being mobile, hiking and visiting tourist destinations has a positive effect on physical and mental health (Flade et al. 2001; Käser 2003). The number of older visitors to conservation areas has also increased with the emergence of theme trails, hiking events and the promotion of nature tourism (Dreyer et al. 2010).

\section{Methods}

During summer and early autumn of 2009, we interviewed 110 visitors over 55 in the SNP, using a qualitative approach and a convenience sample. The interviews were conducted in different locations in the park, mostly in resting areas. We used a problembased guideline interview after Witzel (1985, in Flick 2010, p. 210 f.) that included episodical sections that stimulated interviewees to expand. The interviews were subsequently transcribed, coded and analysed. Main categories were patterns of movement, interests, needs and wishes.

The results of these visitor interviews were discussed with ten experts, selected through theoretical sampling. They included representatives from tourism, the hotel and restaurant sector, public transport, municipalities and the management of the SNP itself. The aim was to get a deeper understanding of the attention given to older visitors in this region and the measures taken to accommodate their growing number and demands.

\section{Older visitors' perception of the SNP}

Visitors to the SNP over 55 mainly come because it is a protected area, where fauna and flora can develop free from human interference: "Nowadays... it is good to have a spot where nature can just remain nature" (woman
60-64). They strongly support strict protective regulations issued by the park management, such as a ban on hunting, fishing, depositing rubbish or leaving the trails. Hence, "nowhere else can you observe chamois and ibex in such a nice way as here, where nobody would disturb them" (man 70-74).

Since the visitors regard the park as the property of the Swiss people, they also want to have access and think they have a right to enter. Some miss the opportunity to enter the park in winter on snow shoes, which is not allowed. However, the motivation for most to visit the park is to hike and observe its natural beauty, especially when ungulates are around. The peak season is from July to August and during the rutting of the red deer. The animals can be observed in Val Trupchun at the end of September: "It is the power, the strength they have, that's really special" (woman 65-69). Most do not come with a single interest but for the park's variety of things to see and do. Older visitors tend to come regularly; $75 \%$ of respondents have visited the park at least once before. Some remember that fifty years ago the forests were in an inferior state and remark on the regeneration that has happened since. Many bring along reference books to identify plants or birds or use binoculars to observe wildlife. They also like to get in touch with park rangers or researchers.

Older visitors often bring along their family and friends: "It is not simply running around getting sweaty and thirsty, it is an incredible deepening of the feeling for nature [for the grandchildren]" (man 75-79).

Almost every visit requires some level of fitness. Therefore, visitors over 80 are very rare in the interior of the park. As frequent visitors, many older people know that they take longer for the trails than advertised on the signposts. Being less surefooted, they require well maintained trails. In general they emphasized that the trails are in excellent condition, except for a few difficult spots where they would have appreciated steps or handrails. They also expect extensive information and adequate maps from the SNP and some also use the digital media offered by the park. Other than that, some (mostly women) would like to see toilets in the larger resting areas and benches to rest rather than having to sit in the grass.

Older visitors have great expectations and want to have them fulfilled. This makes them less tolerant to crowding and inappropriate behaviour. They even scold people who are not observing the rules or report them to the rangers and they are wary of school children whom they describe as loud and undisciplined. As a consequence, they ask for more trails to avoid crowding.

\section{Results of the expert interviews}

The interviews with tourist experts from the region shed a different light on the group of older tourists. They report that while visitors to the SNP in general have a higher level of education than average tourists, 
the older among them are the keenest to learn new things and often come to the visitor centre to get information brochures or buy books. They are frequent participants of excursions offered by SNP management or private organizations. If they are pleased with their experience, they are very grateful guests, states a leaseholder of a park cabin. Moreover, older tourists feel particularly attracted to the park because mountain-bikers - often regarded as a nuisance by them when hiking in other regions - are banned here.

Older people are known as very reliable visitors who often come back every year. They also serve as multiplicators, bringing along friends or family. Knowing about this groups' interests, tour operators offer tailormade tours, excursions and information events. One hotel in a tourist resort explicitly caters for visitors over 50 with larger-print information (including the small print), menus tailored to them and direct access to the nearby spa. Public transport management is also aware of the special needs of this clientele. Timetables are printed in larger fonts and drivers trained to be attentive and informative.

\section{Discussion}

In the SNP we find a special group of exceptionally fit and interested older visitors. The results of our study show that these visitors are exceptionally well informed about the conditions and requirements of the trails as well as about the flora and fauna they are about to encounter. Their desire to experience undisturbed nature is sometimes threatened when crowding occurs or when other visitors break SNP rules. The older visitors not only have clear ideas about their fellow visitors, they also have high expectations of the infrastructure and the quality of information. No other age group shows more interest in background information or more contact with the park rangers. The tourist industry in the area is aware of the potential of this group and has adapted some of their offers to older visitors. In response, these visitors return more often, become regular guests and serve as multiplicators.

\section{Conclusion}

Demographic changes such as the greater number and fitness of older people have consequences for tourism in protected areas. The expectations, needs and wishes expressed by these visitors in the qualitative interviews we conducted point to some adaptations yet to be made by the SNP management and the tourist authorities. Others have been accomplished already or are part of regular park maintenance. Older visitors are very much in favour of the park's management and emphasize that the rules are appropriate and should be enforced even more strictly. They wish for toilets and benches in selected resting areas, but this can probably not be fulfilled. The biggest issue is related to

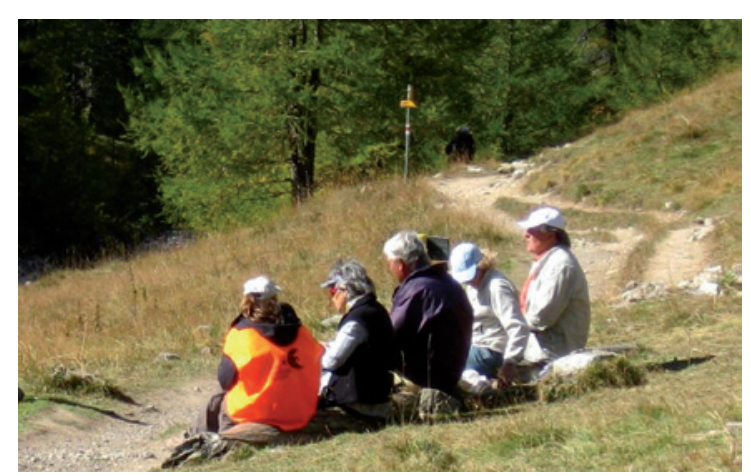

Interviews in the Swiss NP, researcher in the orange vest. (C) Corvin Bulliard

crowding. Older visitors are most sensitive about this and their tolerance for disturbance from other visitors is very low. The park management is well advised to monitor this issue carefully.

\section{References}

Cathomas-Bearth, R. 2001. Mehr Wertschöpfung und Partnerschaft. In: Vereinigung Bündner Umweltorganisationen VBU (Hrsg.), Graubünden weiter als das Auge reicht. 35 Autorinnen und Autoren denken vorwärts: 131-139.

Dreyer, A., A. Menzel \& M. Endress 2010. Wandertourismus. Kundengruppen, Destinationsmarketing, Gesundheitsaspekte. München: Oldenbourg Wissenschaftlicher Verlag GmbH.

Flade, A., M. Limbourg \& B. Schlag 2001. Mobilität älterer Menschen. Opladen: Leske und Budrich.

Flick, U. 2010. Qualitative Sozialforschung. Eine Einführung. Hamburg: Rowohlt Taschenbuch Verlag.

Hennig, S. \& Y. Grossmann 2008. Charakterisierung von Erholungssuchenden in Schutzgebieten im Fokus der Besucherlenkung. Am Beispiel des Nationalparks Berchtesgaden. In: Kopp, H. (Hrsg.), Mitteilungen der fränkischen geographischen Gesellschaft 55: 97-122.

Käser, U. 2003. Freizeitmobilität älterer Menschen, FRAME. http://www.psychologie.uni-bonn.de/fileadmin/entpaed/Download/Kaeser/desergha.pdf. (accessed: 03/08/2010)

Kochsiek, K. \& G. Gieselmann 2009: Körper, Geist, Gesundheit, Hirn. Tagungsprotokoll. In: Hausen zur, H. (Hrsg.), Nova Acta Leopoldina (369)105: 15-51.

Küpfer, I. 2000. Die regionalwirtschaftliche Bedeutung des Nationalparktourismus untersucht am Beispiel des Schweizerischen Nationalparks. Nationalparkforschung Schweiz 90.

Lozza, H. 1996. Tourismusbefragung 1993 im Schweizerischen Nationalpark. Semesterarbeit am Geographischen Institut der Universität Zürich. Nationalparkdirektion: Arbeitsberichte zur Nationalparkforschung. Wissenschaftliche Nationalparkkommission (WNPK).

Möller, C., K. Weiermair \& E. Wintersberger 2007. The Changing Travel Behaviour of Austria's Ageing 
Population and its Impact on Tourism. Tourism Review $62(3,4): 15-20$.

Nimrod, G. 2008. Retirement and Tourism. Themes in Retirees Narratives. Annals of Tourism Research 35 (4): 859-878.

Prahl, H.-W. 2002. Soziologie der Freizeit.

Prahl, H.-W \& K.R. Schröter 1996. Soziologie des Alterns. Eine Einfübrung.

Scheiner, J. 2001. Reisen älterer Menschen: Empirische Befunde und Handlungsstrategien. In: Flade, A., M. Limbourg \& B. Schlag (eds.), Mobilität älterer Menschen.

Thieme, F. 2008. Alter(n) in der alternden Gesellschaft. Eine soziologische Einführung in die Wissenschaft vom Alter(n).

\section{Authors}

Alice Trachsel

Born 1985. Master thesis on the perception of conservation areas by older visitors. Currently working as a geography teacher.

Dept. of Geography, University of Zurich, Winterthurerstr. 190, 8057 Zurich, Switzerland

alice.trachsel@gmail.com

Norman Backhaus (corresponding author)

Born 1963. Habilitation on tourism and conservation in Malaysia. Currently lecturer at the University of $\mathrm{Zu}-$ rich.

Dept. of Geography, University of Zurich, Winterthurerstr. 190, 8057 Zurich, Switzerland norman.backhaus@geo.uzh.ch 